\title{
Control of Lavandula Dentata Root Rot with Leaves Extracts of Lawsonia Inermis and Eucalyptus Camaldulensis
}

\author{
Hanan M.H. Ali*, Nahed S.A. El-Shayeb* and El-Shaer, A.H. ** \\ *Horticulture Research Institute (HRI), Agriculture Research Center (ARC), Giza,Egypt \\ **Plant Pathology Research Institute (PPRI),Agriculture Research Center \\ (ARC),Giza,Egypt
}

\begin{abstract}
A pot experiment was conducted during 2012 and 2013 seasons in the Experimental Field of the Medicinal and Aromatic Plants Department at Dokky, Giza, to investigate the effect of aqueous extracts of powdered dried henna ( Lawsonia inermis) and camphor (Eucalyptus camaldulensis) leaves separately on Lavender ( Lavandula dentata) root rot disease, vegetative growth, volatile oil percentage, volatile oil component analysis (GLC). The results were summarized as follow: in all cuts in the two seasons, treatment inoculated with the tested fungus alone all plants died (control). The plants sprayed with Lawsonia inermis aqueous extract at high concentration $(100 \mathrm{~g} / \mathrm{L})$ had a highest significant antimicrobial activity against root rot disease, Lawsonia inermis aqueous extract showed good inhibitory effect against the tested fungus. As for vegetative growth and volatile oil percentage the application of Lawsonia inermis aqueous extract at $(100 \mathrm{~g} / \mathrm{L})$ significantly increased plant height, number of branches, herb fresh and dry weights and volatile oil percentage in most cases in both seasons. Followed by the application of Eucalyptus camaldulensis aqueous extract at ( $100 \mathrm{~g} / \mathrm{L})$. The lowest values were recorded when the plants were treated with Eucalyptus camaldulensis aqueous extract at $(50 \mathrm{~g} / \mathrm{L})$ in the first and second seasons. Regarding GLC analysis, the highest percentage of 1,8-Cineol (the main component of the volatile oil) was produced with Lawsonia inermis aqueous extract at $(100 \mathrm{~g} / \mathrm{L})$.
\end{abstract}

Keywords Lavandula dentata root rot disease, Lawsonia inermis and Eucalyptus camaldulensis leaves aqueous extracts.

\section{INTRODUCTION}

The intensive and indiscriminate use of fungicides in agriculture has caused many problems to the environment such as water, soil, animals and food contamination, poisoning of farmers elimination of non target organisms and selection of phytopathogens, pest and weed insensitive to certain active ingredients( Strangarlin et al., 1999).To minimize the negative effects of fungicides alternative developed methods to control plant diseases are being used. These methods include the biological control, the induction of resistance and the use of natural products with induction of resistance and or with direct antimicrobial activities (Schwan and Strangarlin, 2005).

The biological control is defined as the use of antagonistic organisms for the control of microorganisms, reducing the amount of inoculum that determines the extent of disease (Cook and Baker, 1983). The induction of resistance promotes the activation of the latent plant defense systems, which manifests itself when it comes into contact with a biotic (Felipini and Di Piero, 2009) on apple and (Strangarlin et al., 2010) on soybean or abiotic elicitor carre and ( Barretti et al., 2010) on tomato. The expression resistance of induction both can be used to denote local protection, this is, the induction of a resistance only in the tissues in which it was applied the treatment with the inducing agent, also 
can indicate a systemic resistance that manifest far from the tissue where the elicitor was applied ( Moraes, 1992).

Henna (Lawsonia inermis) belongs to family Lythraceae is small shrub cultivated in many tropical countries and warm temperate reign. It has been used for coloring palms of hands, soles of feed an finger nails and also for personal adornment (Bhuvane and Kuruvilia, 2002). Lawsonia inermis plant constituent are made up tannic acid, mucilage and gallic acid, but the main bioactive constituent is 2-hyrooxynaphthoquinon (lawsone). (Singh and Singh, 2001) powdered leaves of this plant in paste form have been used as cosmetic and as remedy in skin diseases and used as external application in headache. Lawsonia inermis aqueous extract has been used as natural fungicide (Dahankhar et al., 2000). Also, Lawsonia inermis aqueous extract has a high antimicrobial activity against potato dry rot disease caused by Fusarium solani (Bhardwaj, 2012). Spraying Lawsonia inermis aqueous extract is the safe method to control powdery mildew disease of Zinnia elegans (Hegazi and ElKot, 2010).

Some components in Lawsonia inermis leaves according to (Duke, 1992)

- Lawsone (10 ppm)

1.4 Naphaquinone

- Flavonoid glucosde

Apigenin-4- glucoside

Luteolin-3-glucoside

Luteolin-7-0-glucoside

- Tannins (50-100 ppm)

- Phenolic acid

Gallic acid

- Terpenes

Beta- sitosterol

Mannitol

- Coumarins(12.7-21.4 ppm)

- Sugars

Pentosan

Camphor (Eucalyptus camaldulensis) belongs to family Myrtaceae, is one of the reputed fast growing trees of the world. It's oil is acrid, bitter, astringent and insect repellent,( Babu et al., 2008).

Some components in Eucalyptus camaldulensis leaves according to (Duke, 1992)

- Terpens and their derivatives

Beta-Bisabolol, Beta-Elemene, Beta-Pinene

Borneol, Cadinadiene, Cadinenol, Cadineol

1-8Cineole(24-48ppm), Geraniol, Eugenol

\&-Terpineol- Citronellol, Camphene

Cuminalcohol, Cuminaldehyde, Camphor

Eucalyptol

- Phenolic acidsglocosid 
lavender (Lavandula dentata) belongs to family Lamiaceae. Lavandula dentata is one of the most useful medicinal and aromatic plants. Commercially, it is an important source of essential oil that is widely used in fragrance industry including soaps, colognes, perfumes, skin lotions and other cosmetics (Paul et al., 2004). In food manufacturing, lavender essential oil is employed in flavoring beverages, ice -cream, candy, baked goods and chewing gum (Kim and Lee, 2002) . Recently, aromatherapy is becoming increasingly popular and Lavandula dentata is used in aromatherapy as a relaxant (Lis -Balchin and Hart, 1999).Several therapeutic effects of Lavandula dentata, such as sedative, antiviral and antimicrobial activities have been reported (Gamez et al., 1990 ; Buchbauer et al., 1991).

Lavandula dentata essential oil are advocated for their use as antibacterial agent in both early and modern aromatherapy texts (Lawless,1992; Gattefosse,1995). Lavandula dentata is exposed to many diseases and root rot is one of the Botryodiplodia theobromae (Pat.) Griff. and Maubl. (Syn: Lasiodiplidia theobromae Pat.) and its asexual state, Botryosphaeria rhodina (Berk and M.A. Curtis) Arx are fungal pathogens of great economic importance.It is a cosmopolitan fungus causing both field and storage diseases on more than 280 plant species including crops, fruits, and cash fruit trees . $B$. theobromae is an opportunistic plant pathogen that causes different types of plant diseases within tropical and subtropical regions ( Faber et al., 2007). It has a wide host range estimated to be more than 280 plant species (Domsch et al., 2007; Khanzada et al., 2006; Sutton 1980) although with varied pathological effects on its hosts. The fungus is known to cause tuber rots in yam, root rot in cassava, collar rot in peanuts, crown rot in banana, stem end rot in mango fruits, stem rot in pawpaw and leaf spot in citrus (Sangeetha et al., 2011; Rossel et al., 2008; Khanzada et al., 2004). Rots caused by the fungus, particularly in the root and tuber crops often occur underground and so diagnosis of the disease is usually delayed or under repaired. Moreover, the wider host range (Crammer, 1979) and the host non- specificity of $B$. theobromae makes control and management of the disease very difficult.

Nawadays synthetic fungicides are used as primary tools for the control of plant diseases. However, the alternative control methods are needed because of the negative public perceptions about using synthetic chemicals, resistance to fungicide among fungal pathogens, and high development cost of new chemicals. The uses of plant-derived products as disease control agents have been studied, since they tend to have low mammalian toxicity, less environmental effects and wide public acceptance (Lee et al., 2007; Katooli et al., 2011).

The aim of this research was to examin the antifungal activity of aqueous extracts of Lawsonia inermis and Eucalyptus camaldulensis leaves separately to control of Lavandula dentata plants root rot disease . 


\section{MATERIALS AND METHODS}

This experiment was conducted at the Experimental Field of the Medicinal and Aromatic Plants Department at Dokky, Giza, Egypt, in two successive seasons 2012 and 2013.

\section{Preparation of Plant extracts}

Lawsonia inermis and Eucalyptus camaldulensis aqueous extracts were prepared by soaking $(100 \mathrm{~g})$ of powdered dried leaves in tap water for 24 hours and then they were filtered. Each extract was concentrated at (50 and $100 \mathrm{~g} / \mathrm{L})$ (Babu et al., 2008).Lavandula dentata plants were sprayed four times with aqueous extracts of Lawsonia inermis and Eucalyptus camaldulensis separately. The first spray was conducted after planting, the second was done three weeks there after, the third was applied after the $1^{\text {st }}$ cut and the fourth was added three weeks after the third one.

\section{Experimental procedure}

\subsection{Isolation and identification of causal pathogen (Botryodiplodia theobromae )}

Naturally infected plants showed root rot disease symptoms, collected from El-Ekhlas Farm at Giza, were cut into pieces $5 \mathrm{~mm}$ long. These pieces were surface sterilized for $3 \mathrm{~min}$. with $3 \%$ sodium hypochlorite and rinsed in 4 successive changes of sterile distilled water then left to dry on Whatman No. 1 filter paper. The surface sterilized pieces were transformed to potato dextrose agar (PDA) medium in petri dishes and incubated at $27 \pm 2^{\circ} \mathrm{C}$ for 5 days . Pure cultures, made by single spore technique, was identified using cultural, morphological and microscopical characters according to (Barnett and Hunter, 1981).

\subsection{Soil infestation with the pathogenic fungus}

Isolated pathogen Botryodiplodia theobromae was grown on sand -corn medium(1:1w:w and $40 \%$ water ) for 15 days at $25 \pm 2^{\circ} \mathrm{C}$.Pots (30cm diameter) containing sterilized sandy loam soil were artificially infested separately with prepared fungal inoculum at the rate $3 \%$ of soil weight. The inoculum was mixed thoroughly with the upper layer of the soil then irrigated every other day and left for 7 days to ensure the distribution of the inoculum. Each treatment was replicated three times every replicate consisted of nine pots (1 plant / pot) and nine ones left without infestation to serve as control. Root rot percentage was recorded 45 days after planting.

\subsection{Source of cutting}

Lavandula dentata cutting $(15-20) \mathrm{cm}$ in height were obtained from ElEkhlas Farm at Giza and planted in plastic pots $\left(30 \mathrm{~cm}\right.$ diameter) on $25^{\text {th }}$ February, 2012 and 2013 in the first and second seasons, respectively. 


\section{Experiment layout}

The experiment layout was designed in complete randomized blocks included five treatments each treatment was replicated three times and every replicate consisted of nine pots (1plant /pot), the recorded data were statistically analyzed according to Snedecor and Conchran (1968), using L.S.D at 5\% .

\section{Chemical fertilization}

The sources of chemical fertilizers (NPK) were ammonium sulphate $(20.6 \% \mathrm{~N})$, calcium superphosphate $\left(15.5 \% \quad \mathrm{P}_{2} \mathrm{O}_{5}\right)$ and potassium sulphate $\left(48 \% \mathrm{~K}_{2} \mathrm{O}\right)$. (NPK) fertilizers were added at the recommended level in five doses, the $1^{\text {st }}$ was for all phosphorous amount which was added during soil preparation, the rest (NK) were applied in two equal doses for each cut, on $8{ }^{\text {th }}$ April and $10^{\text {th }}$ May for the $1^{\text {st }}$ cut and on $10^{\text {th }}$ June (after the $1^{\text {st }}$ cut) and $9^{\text {th }}$ July for the $2^{\text {ed }}$ one in the two seasons. The plants were harvested twice, the first cut was conducted on $7^{\text {th }}$ June and the second one on $8^{\text {th }}$ August in both seasons.

\section{Treatments}

1.Control (Botryodiplodia theobromae fungus all plants died and were not subject to statistical analysis ) .

2. Botryodiplodia theobromae fungus+ Lawsonia inermis aqueous extract at $(50 \mathrm{~g} / \mathrm{L})$.

3.Botryodiplodia theobromae fungus +Eucalyptus camaldulensis aqueous extract at $(50 \mathrm{~g} / \mathrm{L})$.

4. Botryodiplodia theobromae fungus + Lawsonia inermis aqueous extract at $(100 \mathrm{~g} / \mathrm{L})$.

5.Botryodiplodia theobromae fungus +Eucalyptus camaldulensis aqueous extract at $(100 \mathrm{~g} / \mathrm{L})$.

\section{Data recorded}

The following data were recorded

1. Identification of causal pathogen (Botryodiplodia theobromae )

2.Percentage of root rot.

3.Plant height and number of branches /plant.

4. Herb fresh and dry weights ( $\mathrm{g} / \mathrm{plant}$ ).

5.Volatile oil percentage in fresh herb according to (British Pharmacopeia, ,1963).

\section{Volatile oil component}

Sample taken from the oil obtained in the first cut of the first season were analyzed using gas liquid chromatography (GLC), to determine their main constituents. The use of GLC in the quantitative determinations was performed using the methods described by (Bunzen et al., 1969; Hoftman, 1967). 


\section{RESULTS AND DISCUSSION}

\section{Identification of causal pathogen}

Associated with root rot symptoms was a fungus that had the following morphology: solitary pycnidia, pyriform, black, 150-175 X190-210 mm, glabrous, with an apical ostiole, stromatic wall, composed of several layers of dark brown, thick-walled cells; conidia ellipsoidal, one-celled, hyaline when immature becoming dark brown, striate and didymospore with age ,22.0-28.5 X12.5-14.0 mm. The fungus fits the description of Botryodiplodia theobromae (Pat.) Griffon \& Maubl. (Punithalingam, 1976 ; Barnett and Hunter, 1981).

\section{Percentage of root rot}

Aqueous extracts of Lawsonia inermis and Eucalyptus camaldulensis were tested for their antifungal ability to control root rot disease of Lavandula dentata caused by the pathogenic fungus Botryodiplodia theobromae. Data in Table (1) clearly emphasized that, Lawsonia inermis and Eucalyptus camaldulensis aqueous extracts separately control root rot disease. It is obvious that resistance agents significantly decreased the incidence of root rot disease, Lavandula dentata plants were protected by aqueous extracts of Lawsonia inermis and Eucalyptus camaldulensis separately. The most effective treatment was aqueous extract of Lawsonia inermis at $100 \mathrm{~g} / \mathrm{L}$ in both seasons. This result may be due to medicinal and aromatic plants represent a rich source of antimicrobial agents ( Mahesh and Satish, 2008). Plants generally produce many secondary metabolites, fungicides and many pharmaceutical agents used in traditional medicine (Ibrahim, 1997; Ogundipe et al., 1998).Medicinal and aromatic plants are the sources of natural fungicides that make excellent leads for new fungicides development (Arokiyara et al., 2008; Brindha et al., 2009). Also Medicinal and aromatic plants have limitless ability to synthesize aromatic secondary metabolites, most of which are phenols or their oxygen subatituted derivatives (Geissman, 1963). Important subciasses in this group of compounds include phenols, phenolic acids, quinones, flavones, flavonoids, tannins, coumarins and essential oils. These groups of compounds show antimicrobial effect and serves as plant defense mechanisms against pathogenic microorganisms. Simple phenols and phenolic acid are bioactive phytochemicals consisting a single substituted phenolic ring. Phenolic toxicity to microorganisms is due to the sites and number of hydroxyl groups present in the phenolic compound( Scalbert, 1991; Urs and Dunteavy, 1975).Quinones are characteristically highly reactive, colored compounds. These results were in accordance to ( Bambawale et al., 1995) on cotton found that, Lawsonia inermis aqueous extract inhibited spore germination and mycelial growth of Myrothecium roridum. Also, (Bakeer et al., 2005) on Pelargonium graveolens reported that, garlic (Allium sativum) and onion (Allium cepa) extracts significantly decreased the incidence of Pelargonium graveolens root rot disease. (Sharma et al., 2010) on kinnow fruits observed that, Allium sativum aqueous extract inhibited $100 \%$ of mycelial growth of Botryodiplodia theobromae followed by aqueous extract of Lawsonia inermis which reduced $73.64 \%$ of rot incidence. 
Table 1. Effect of Lawsonia inermis and Eucalyptus camaldulensis leaves extracts on percentage of root rot of Lavandula dentata plants during 2012 and 2013 seasons

\begin{tabular}{lcccc}
\hline \multirow{2}{*}{ Treatments } & \multicolumn{4}{c}{$\%$ root rot } \\
\cline { 2 - 5 } & Season 2012 & Efficacy \% & Season 2013 & Efficacy \% \\
\hline $\begin{array}{l}\text { Control( Botryodiplodia theobromae fungus) } \\
\text { Botryodiplodia theobromae fungus }\end{array}$ & 100.00 & 0.0 & 100.00 & 0.0 \\
+ Lawsonia inermis extract (50g/L) & 41.60 & 53.70 & 38.90 & 56.70 \\
$\begin{array}{l}\text { Botryodiplodia theobromae fungus } \\
\text { +Eucalyptus camaldulensis extract (50g/L) }\end{array}$ & 46.60 & 48.20 & 44.40 & 50.60 \\
$\begin{array}{l}\text { Botryodiplodia theobromae fungus } \\
\text { +Lawsonia inermis extract (100g/L) }\end{array}$ & 27.50 & 69.10 & 25.50 & 72.20 \\
$\begin{array}{l}\text { Botryodiplodia theobromae fungus } \\
\text { +Eucalyptus camaldulensis extract(100g/L) }\end{array}$ & 39.60 & 56.00 & 36.60 & 59.30 \\
LSD at 5\% & 15.40 & - & 14.60 & - \\
\hline
\end{tabular}


The same results were obtained by (Hegazi and El-Kot, 2010) found that, spraying Zinnia elegans plants with Lawsonia inermis aqueous extract inhabited powdery mildew caused by Erysiphe cichoracearum fungus. In the same way, (Tariqu et al., 2010) on Gladiolus grandiflorus stated that, spraying both aqueous extracts of Allium sativum and Allium cepa reduced incidence of corm rot disease caused by Fusarium oxysporium fungus.

\section{Vegetative growth}

\subsection{Plant height and number of branches/ plant}

Data in Table (2) indicated that, treatment inoculated with Botryodiplodia theobromae fungus alone all plants died (control), also both aqueous extracts of Lawsonia inermis and Eucalyptus camaldulensis had a significant increased in plant height and number of branches / plant in the two seasons. The tallest plants in the first and second seasons at the two cuts were recorded by the plants were treated with aqueous extract of Lawsonia inermis and Eucalyptus camaldulensis separately at $100 \mathrm{~g} / \mathrm{L}$ which gave $(36.36,34.77 \mathrm{~cm})$ and $(29.16$, $27.36 \mathrm{~cm}$ ) at first and second cuts in the first season, respectively. The same trend was observed in the second season giving $(32.50,31.77 \mathrm{~cm})$ and $(26.97,25.30 \mathrm{~cm})$. The shortest plants in the two cuts of the first and second season were treated with aqueous extract of Eucalyptus camaldulensis at $50 \mathrm{~g} /$ $\mathrm{L}$ as shown in Table (2). The same trend was observed in the case of number of branches. The application of Lawsonia inermis aqueous extract also had a significant effect on number of branches/plant, the highest number of branches was recorded when plants were sprayed with Lawsonia inermis aqueous extract at $100 \mathrm{~g} / \mathrm{L}$ giving 9.35 and 10.07 at first and second cuts, respectively, while in the second season the recorded data were 12.01 and 13.15 at first and second cuts, respectively. The lowest values were recorded when the plants were sprayed with Eucalyptus camaldulensis aqueous extract at $50 \mathrm{~g} / \mathrm{L}$ in the first and second cuts at the first season giving (7.46 and 8.90). The same trend was observed in the second season giving $(9.60,10.96)$ at the first and second cuts. These results may be due to Lawsonia inermis aqueous extract contains lawsone $\left(\mathrm{C}_{10} \mathrm{H}_{6} \mathrm{O}_{3}\right)$, the active

ingrediend and naturally occurring naphthoquinone (Habbal et al., 2007) and the presence of eucalyplol in Eucalyptus camaldulensis aqueous extract (Babu et al., 2008).These results are in agreement with that obtained by (Tariqu et al., 2010) on Gladiolus grandiflorus.

\subsection{Herb fresh and dry weights (g/ plant)}

Data in Table (3) revealed that, treatment applied with the tested fungus alone all plants died (control). Spraying aqueous extracts of Lawsonia inermis and Eucalyptus camaldulensis separately had a significant effect on herb fresh and dry weights in most cases in the two seasons. The best results were obtained from Lawsonia inermis aqueous extract. The highest fresh and dry weights /plant were recorded when Lavandula dentata plants were sprayed with Lawsonia inermis aqueous extract at $100 \mathrm{~g} / \mathrm{L}$ giving $37.15,39.31 \mathrm{~g} / \mathrm{plant}$ and 41.43, $48.44 \mathrm{~g} / \mathrm{plant}$ fresh weight and 15.47, $19.88 \mathrm{~g} / \mathrm{plant}$ and 28.09,37.12 $\mathrm{g} /$ plant dry weight in the first and second seasons respectively. 
Table 2. Effect of Lawsonia inermis and Eucalyptus camaldulensis leaves extracts on plant height and number of branches of lavandula dentata plants during 2012 and 2013 seasons

\begin{tabular}{|c|c|c|c|c|}
\hline \multicolumn{5}{|c|}{ Plant height } \\
\hline & \multicolumn{2}{|c|}{$1^{\text {st }}$ season } & \multicolumn{2}{|c|}{$2^{\text {ed }}$ season } \\
\hline Treatments & $1^{\text {st }}$ cut & $2^{\mathrm{ed}}$ cut & $1^{\text {st }}$ cut & $2^{\text {ed }}$ cut \\
\hline Control( Botryodiplodia theobromae fungus) & 0.0 & 0.0 & 0.0 & 0.0 \\
\hline $\begin{array}{l}\text { Botryodiplodia theobromae fungus + Lawsonia inermis } \\
\text { extract }(50 \mathrm{~g} / \mathrm{L})\end{array}$ & 23.81 & 22.05 & 21.80 & 20.15 \\
\hline $\begin{array}{l}\text { Botryodiplodia theobromae fungus +Eucalyptus } \\
\text { camaldulensis extract }(50 \mathrm{~g} / \mathrm{L})\end{array}$ & 23.23 & 20.42 & 20.17 & 19.67 \\
\hline $\begin{array}{l}\text { Botryodiplodia theobromae fungus }+ \text { Lawsonia inermis } \\
\text { extract }(100 \mathrm{~g} / \mathrm{L})\end{array}$ & 36.36 & 34.77 & 32.50 & 31.77 \\
\hline $\begin{array}{l}\text { Botryodiplodia theobromae fungus }+ \text { Eucalyptus } \\
\text { camaldulensis extract }(100 \mathrm{~g} / \mathrm{L})\end{array}$ & 29.16 & 27.36 & 26.97 & 25.30 \\
\hline LSD at5\% & 3.326 & 3.664 & 4.044 & 4.962 \\
\hline \multicolumn{5}{|c|}{ Number of branches } \\
\hline Control( Botryodiplodia theobromae fungus) & 0.0 & 0.0 & 0.0 & 0.0 \\
\hline $\begin{array}{l}\text { Botryodiplodia theobromae fungus + Lawsonia inermis } \\
\text { extract }(50 \mathrm{~g} / \mathrm{L})\end{array}$ & 8.56 & 9.43 & 9.99 & 11.33 \\
\hline $\begin{array}{l}\text { Botryodiplodia theobromae fungus +Eucalyptus } \\
\text { camaldulensis extract }(50 \mathrm{~g} / \mathrm{L}\end{array}$ & 7.46 & 8.90 & 9.60 & 10.96 \\
\hline $\begin{array}{l}\text { Botryodiplodia theobromae fungus }+ \text { Lawsonia inermis } \\
\text { extract }(100 \mathrm{~g} / \mathrm{L})\end{array}$ & 9.35 & 10.07 & 12.01 & 13.15 \\
\hline $\begin{array}{l}\text { Botryodiplodia theobromae fungus }+ \text { Eucalyptus } \\
\text { camaldulensis extract }(100 \mathrm{~g} / \mathrm{L})\end{array}$ & 9.07 & 9.94 & 11.00 & 12.18 \\
\hline LSD at $5 \%$ & 1.028 & 0.955 & 0.686 & 0.784 \\
\hline
\end{tabular}


These results may due to the presence of the secondary metabolites, flavonoids, tannins, phenols and anthraquinones in Lawsonia inermis aqueous extract, the plant extracts may be considered as good sources of natural antioxidants for medicine uses (Arulpriya and Lalitha, 2012). These results are in harmony with (Muhammed, 2005; Tariqu et al., 2010).

\section{Volatile oil percentage}

Data in Table (4) showed that, all plants died when they were treated with the pathogenic fungus alone (control). Essential oil percentage of Lavandula dentata fresh herb were significantly responded to plant extracts (natural fungicides) in the first season at the two cuts. The high concentration of Lawsonia inermis aqueous extract $(100 \mathrm{~g} / \mathrm{L})$ had a highest fungitoxic activity against Lavandula dentata root rot, which gave the highest oil percentage the values were 0.367 and $0.427 \%$ at the first and second cuts in the first season respectively. While in the second season the differences between the treatments were not significant. The lowest volatile oil percentage was obtained when the plants were sprayed with Eucalyptus camaldulensis aqueous extract at $50 \mathrm{~g} / \mathrm{L}$ in the two seasons. The increment in volatile oil percentage may be due to medicinal and aromatic plants are the sources of natural fungicides because plants produce secondary metabolites such as phenols, phenolic acids, quinones, flavones, flavonoids, flavonols, tannins, coumarins and essential oils. These groups have antimicrobial effect against pathogenic microorganisms (Das et al., 2010).

\section{GLC analysis of essential oil}

The GLC analysis were carried out on the essential oil of Lavandula dentata plants of two treatments in the first cut of first season, Eucalyptus camaldulensis aqueous extract $(50 \mathrm{~g} / \mathrm{L})$ and Lawsonia inermis aqueous extract $(100 \mathrm{~g} / \mathrm{L})$. Data were recorded in Table (5) and Figures (1-2) revealed that, 1,8- Cineol was the main component. It was observed that content of 1,8Cineol tended to increase up to $46.48 \%$ in case of Lawsonia inermis aqueous extract $(100 \mathrm{~g} / \mathrm{L})$. 
Table 3. Effect of Lawsonia inermis and Eucalyptus camaldulensis leaves extracts on herb fresh and dry weights /plant (g) of Lavandula dentata plants during 2012 and 2013 seasons

\begin{tabular}{|c|c|c|c|c|}
\hline \multicolumn{5}{|c|}{ herb fresh weight /plant(g) } \\
\hline \multicolumn{3}{|c|}{$1^{\text {st }}$ season } & \multicolumn{2}{|c|}{$2^{\text {ed }}$ season } \\
\hline Treatments & $1^{\text {st }}$ cut & $2^{\text {ed }}$ cut & $1^{\text {st }}$ cut & $2^{\text {ed }}$ cut \\
\hline Control( Botryodiplodia theobromae fungus) & 0.0 & 0.0 & 0.0 & 0.0 \\
\hline $\begin{array}{l}\text { Botryodiplodia theobromae fungus + Lawsonia } \\
\text { inermis extract }(50 \mathrm{~g} / \mathrm{L})\end{array}$ & 34.61 & 36.07 & 36.94 & 44.17 \\
\hline $\begin{array}{l}\text { Botryodiplodia theobromae fungus }+ \text { Eucalyptus } \\
\text { camaldulensis extract }(50 \mathrm{~g} / \mathrm{L}\end{array}$ & 33.60 & 34.42 & 34.97 & 42.72 \\
\hline $\begin{array}{l}\text { Botryodiplodia theobromae fungus + Lawsonia } \\
\text { inermis extract }(100 \mathrm{~g} / \mathrm{L})\end{array}$ & 37.15 & 39.31 & 41.43 & 48.44 \\
\hline $\begin{array}{l}\text { Botryodiplodia theobromae fungus }+ \text { Eucalyptus } \\
\text { camaldulensis extract }(100 \mathrm{~g} / \mathrm{L})\end{array}$ & 35.07 & 38.33 & 40.78 & 47.52 \\
\hline LSD at $5 \%$ & 3.189 & NS & 5.428 & 4.927 \\
\hline \multicolumn{5}{|c|}{ herb dry weight /plant(g) } \\
\hline $\begin{array}{l}\text { Control(Botryodiplodia theobromae fungus) } \\
\text { Botryodiplodia theobromae fungus + Lawsonia } \\
\text { inermis extract ( } 50 \mathrm{~g} / \mathrm{L} \text { ) }\end{array}$ & $\begin{array}{c}0.0 \\
10.94\end{array}$ & $\begin{array}{c}0.0 \\
17.47\end{array}$ & $\begin{array}{c}0.0 \\
24.64\end{array}$ & $\begin{array}{c}0.0 \\
34.47\end{array}$ \\
\hline $\begin{array}{l}\text { Botryodiplodia theobromae fungus +Eucalyptus } \\
\text { camaldulensis extract }(50 \mathrm{~g} / \mathrm{L}\end{array}$ & 8.75 & 16.08 & 20.27 & 30.48 \\
\hline $\begin{array}{l}\text { Botryodiplodia theobromae fungus + Lawsonia } \\
\text { inermis extract }(100 \mathrm{~g} / \mathrm{L})\end{array}$ & 15.47 & 19.88 & 28.09 & 37.12 \\
\hline $\begin{array}{l}\text { Botryodiplodia theobromae fungus }+ \text { Eucalyptus } \\
\text { camaldulensis extract }(100 \mathrm{~g} / \mathrm{L})\end{array}$ & 13.13 & 18.03 & 26.25 & 35.33 \\
\hline LSD at $5 \%$ & 2.612 & 3.517 & 4.255 & 3.831 \\
\hline
\end{tabular}


Table 4. Effect of Lawsonia inermis and Eucalyptus camaldulensis leaves extracts on volatile oil percentage of Lavandula dentata plants during 2012 and 2013 seasons

\begin{tabular}{|c|c|c|c|c|}
\hline \multicolumn{5}{|c|}{ Volatile oil percentage (in fresh herb) } \\
\hline & \multicolumn{2}{|c|}{$1^{\text {st }}$ season } & \multicolumn{2}{|c|}{$2^{\text {ed }}$ season } \\
\hline Treatments & $1^{\text {st }}$ cut & $2^{\text {ed }}$ cut & $1^{\text {st }}$ cut & $2^{\text {ed }}$ cut \\
\hline Control( Botryodiplodia theobromae fungus) & 0.0 & 0.0 & 0.0 & 0.0 \\
\hline $\begin{array}{l}\text { Botryodiplodia theobromae fungus +Lawsonia inermis } \\
\text { extract }(50 \mathrm{~g} / \mathrm{L})\end{array}$ & 0.220 & 0.407 & 0.453 & 0.500 \\
\hline $\begin{array}{l}\text { Botryodiplodia theobromae fungus +Eucalyptus } \\
\text { camaldulensis extract }(50 \mathrm{~g} / \mathrm{L}\end{array}$ & 0.200 & 0.373 & 0.447 & 0.493 \\
\hline $\begin{array}{l}\text { Botryodiplodia theobromae fungus + Lawsonia inermis } \\
\text { extract }(100 \mathrm{~g} / \mathrm{L})\end{array}$ & 0.367 & 0.427 & 0.460 & 0.520 \\
\hline $\begin{array}{l}\text { Botryodiplodia theobromae fungus +Eucalyptus } \\
\text { camaldulensis extract( } 100 \mathrm{~g} / \mathrm{L})\end{array}$ & 0.273 & 0.413 & 0.454 & 0.513 \\
\hline LSD at $5 \%$ & 0.086 & 0.031 & NS & NS \\
\hline
\end{tabular}

Table 5. Effect of Lawsonia inermis and Eucalyptus camaldulensis leaves extracts on volatile oil components $\%$ of Lavandula dentata plants in the $1^{\text {st }}$ Season $\left(1^{\text {St }}\right.$ cut).

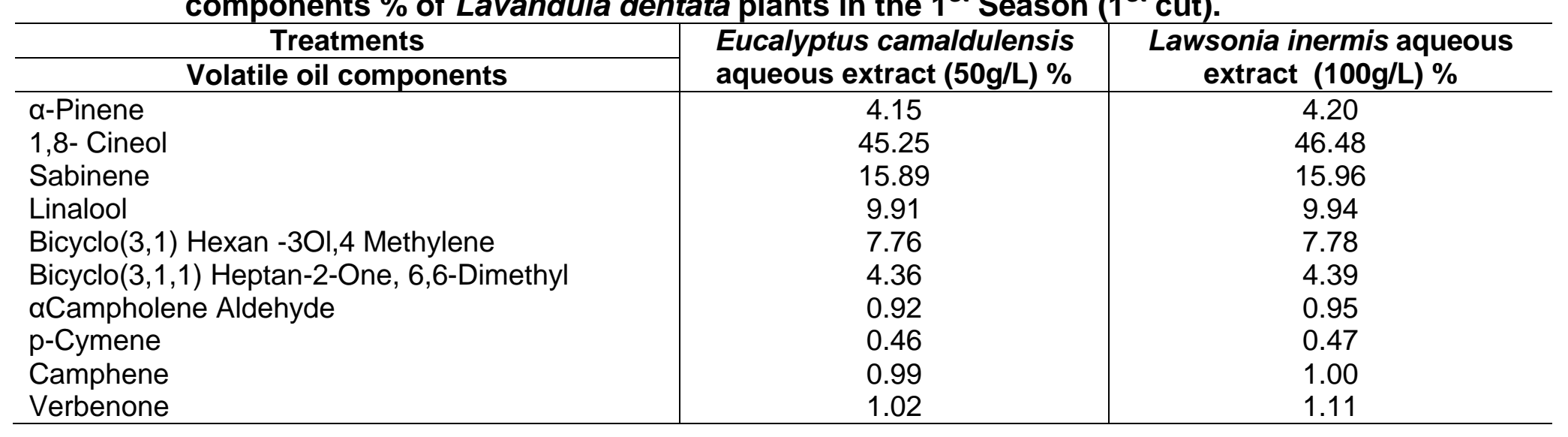




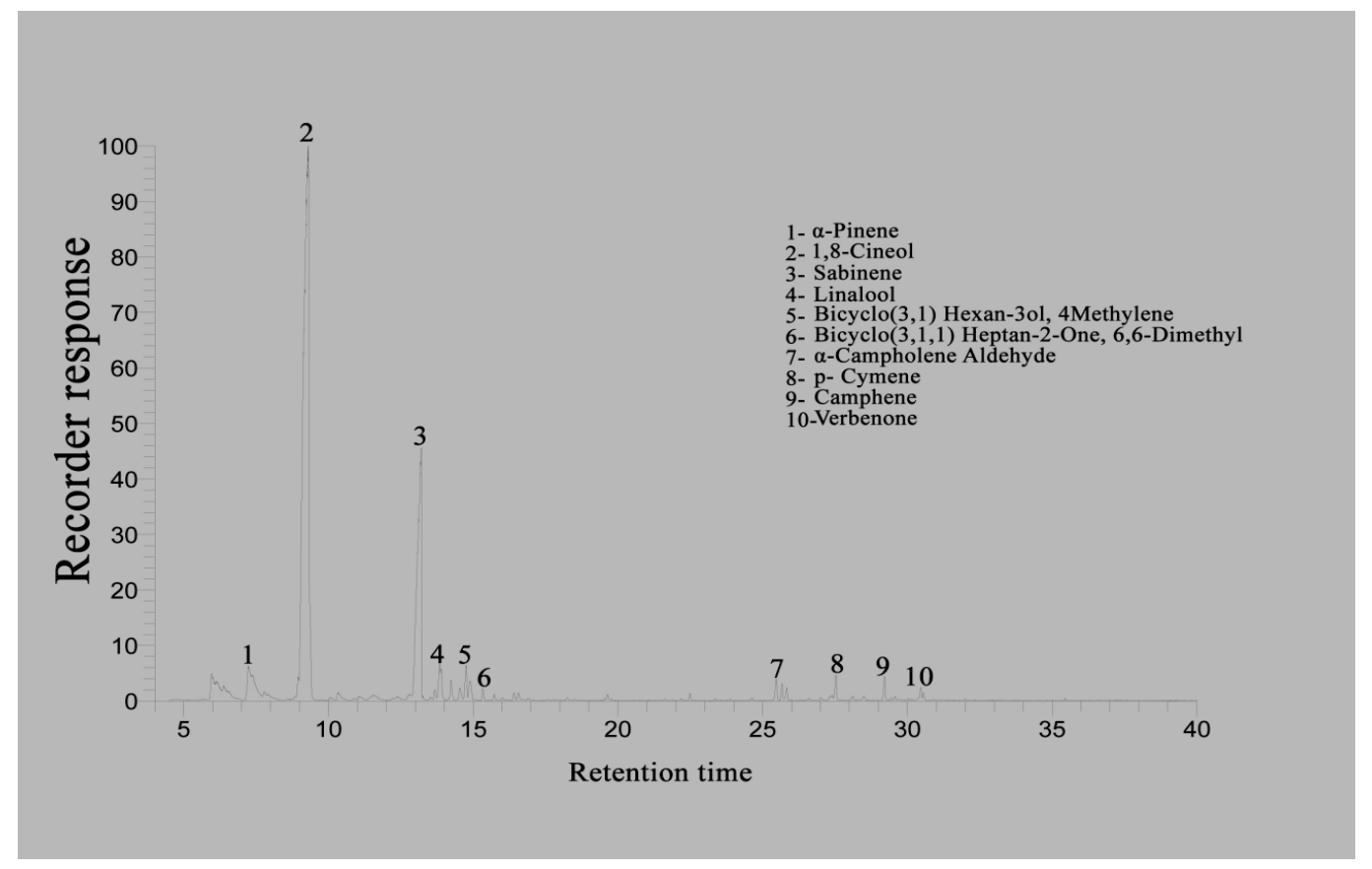

Figure 1. Chromatogram of Lavandula dentata volatile oil distilled from plants sprayed with Eucalyptus camaldulensis leaves aqueous extract at $(50 \mathrm{~g} / \mathrm{L})$

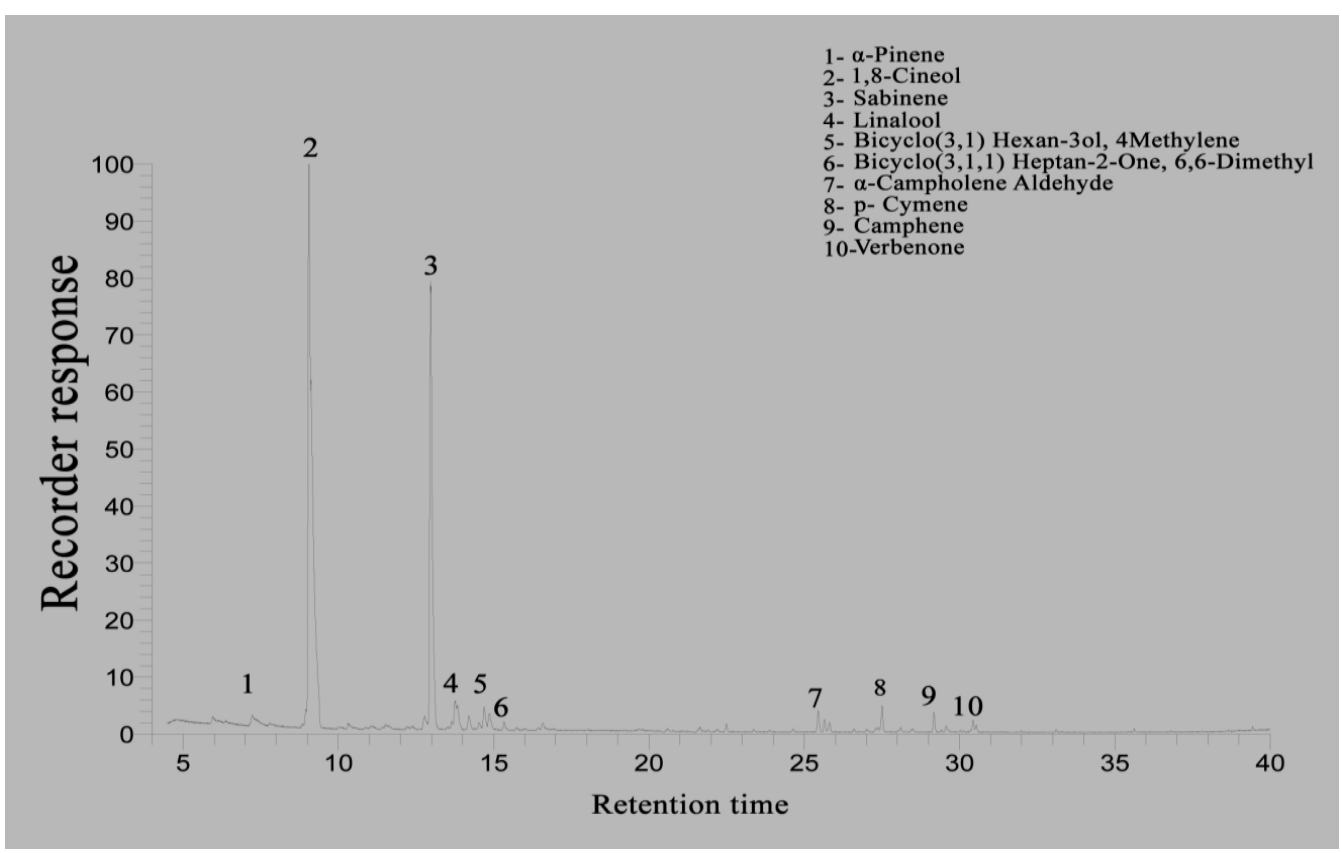

Figure 2. Chromatogram of Lavandula dentata volatile oil distilled from plants sprayed with Lawsonia inermis leaves aqueous extract at $(100 \mathrm{~g} / \mathrm{L})$. 


\section{CONCLUSION}

It could be concluded that Lawsonia inermis aqueous extract at high concentration $(100 \mathrm{~g} / \mathrm{L})$ had a highest (natural fungicide) fungitoxic activity against Lavandula dentata root rot disease and it had a positive effects on vegetative growth and volatile oil percentage.

\section{REFERENCES}

Arokiyara,S., Martin, S. Perinbam, k. , Marie, P.and Beatrice,V.(2008).Free radical Scavenging activity and HPTLC finger print of Pterocarpus santalinus $L-$ an in vitro study.Indian.J.Sci.Technol.,1(7):1-7.

Arulpriya, P.and Lalitha, P.(2012). Assessment of the antioxidant activity of acetone, ethyl alcohol and aqueous extracts of the aerial roots of Pothosaurea (Linden ex Andre) climbed over Lawsonia inermis and Areca catechu. Journal of Chemical and Pharmaceutical Research,(4):1042-1047.

Babu, J., Muzafar,A. and Vinod, K.(2008). Bioefficacy of plant extracts to control Fusarium solani.F.Sp. melongenae of brinjal wilt.Globa Journal of Biotechnology\& Biochemistry,3(2):56-59.

Bakeer, A.T., Shalaby, O.Y., El-Refaei, M. I. and Wafaa, E. H . (2005). Effect of some plant extracts and essential oils of medicinal and aromatic plants on the incidence of pelargonium root rot. Annal of Agricultural science, Moshtohor,(4):1643-1658.

Bambawale, O. M. , Punit, M. and Mukta, C.(1995). Efficacy of some medicinal plants against cotton pathogens.Advances in Plant Sciences, 8(2):224-229.

Barnett, H. L. and Hunter, B.B. (1981). Iliustrated genera of imperfect fungi, MeMillan Pub., London,218pp.

Barretti, P. B. , Souza, R. M. , Pozza, E. A. and Resende, M.L.V. (2010). Aplicacao e doses de acibenzolar.S- metilnaprotecaocentra a muchabacteriana, populacao de pat ogeno e crescimento do tomateiro.Tropical Plant Pathology, 35:229-235.

Bhardwaj, S.K. (2012). Evaluation of plant extracts as antifungal agent against Fusarium solani (Mart.) Sacc. World Journal of Agricultural Sciences, 8(2): 385- 388.

Bhuvane, S. and Kuruvilia, S.(2002).Inhibitory concentration of Lawsonia inermis dry powered for urinary pathogens. Indian Journal of Pharmacology, 34: 260-263.

Brindha, V., Saravan, A. and Manimekalai ,R.(2009).Drug and designing for ring finger protein 110 involved in aden o carcinoma (human breast cancer) using casuarinin extracted from Terminalia arjuna. Indian. J. Sci. Technol,(2):22-26.

British Pharmacopeia (1963). The pharmaceutical press 17 bloom sbury square, London W.C.L.

Buchbauer, G. , Jirevetz, L., Jaeger, W. , Dietrich, H., Plank, C. and Karamat, E. (1991). Aromatherapy : evidence for sedative effects of essential oil of lavender after inhalation. Naturforsch, $46:$ 1067-1072. 
Bunzen, J. N. , Guichard, J. , Labbe, P. , Prevot, J. ,Sperpinetand, J. and Tranchant, J. (1969). Practical manual of Gas Chromatography. J.Tranchant, Ed., El-Seivier Publ.Co., Amesterdam-London.

Cook, R.J. and Baker, K.F.(1983).The Nature and Practice of Biological Control of Plant Pathogens. St. Paul: APS Press.

Crammer, J. (1979). Botryodiplodia theobromae. Common Wealth Mycological Institute, Kew, Surrey. P. 123.

Dahankhar, S.A, Kulkarni, R.A. and Rege, N.N.(2000).Pharmacology of medicinal plants and natural products. Indian. J .Pharmacol, 32: 8-118.

Das, K, Tiwari, R.K.S. and Shrivastava. K (2010).Techniques for evaluation of medicinal plant products as antimicrobial agent, current methods and future trends.Journal of Medicinal Plants Research, 4(2):104-110.

Domsch, K.H., Gams, W. and Anderson, T.H. (2007). Compendium of Soil Fungi. 2nd Ed. Cornell University. England. ISBN 3930167697, 9783930167692.

Duke, J. A. (1992). Handbook of Phytochemical Constituents of GRAS Herb and Other Economic Plants.Boca Raton,FI.CRC Press.

Faber, G.A., Bender, G.S. and Ohr, H.D. (2007). Diseases. UC IPM Pest management Guidelines. UC ANR publication. P. 3436.

Felipini, R.B. and Di Piero, R.M. O. (2009) .Reduction of the severity of apple bitter rot by fruit immersion in chitosan. Pesquisa Agropecuaria Brasileira, 44:1591-1597.

Gamez, M.J., Jimenez, J., Navarro,C. and Zarzuelo,A.(1990). Study of the essential oil of Lavandula dentata L. Pharmazie, 45 : 69-76.

Gattefosse, R.M. (1995). Gattefosse Aromatherapy Essex.CW Daniel Company.

Geissman, T.A. (1963).Flavonoid compounds, tannis, lignins and related compounds. In Florkin, M.Stotz, E.H.(eds). Prrole pigments, isoprenoid compounds and phenolic plant constituents, Elsevier, New York, N.Y.265p.

Habbal, O. A., Al- Jabri, A. A. and El- Hag, A. G. (2007). Antimicrobial properties of Lawsonia inermis (henna). Australian Journal of Medical Herbalism, 19:114-125.

Hegazi, M.A. and El-Kot, G. A. (2010).Biological control of powdery mildew on Zinnia elegans, L. using some bio control agents and plant extracts. Journal of Agricultural Science (Toronto),(2):221-230.

Hoftman, E. (1967). Chromatography. Reinhold Publ. Corp. 2nd Ed., 208-515.

Ibrahim,M.B.(1997).Antimicrobial activity of some important medicinal plant against plant and human pathogens. World .J. Agri.Sci.,4(2):839-843.

Katooli, N. , Raheleh, M. and Seyed, E.R. (2011). Evaluation of eucalyptus essential oil against some plant pathogenic fungi. Journal of Plant Breeding and Crop Science, 3 (2): 41-43.

Khanzada, M.A., Rajput, Q.A. and Shahzad, S. (2006). Effect of medium, temperature, light and inorganic fertilizers on In Vitro Growth and sporulation of Lasiodiplodia theobromae isolated from mango. Pak. J. Bot. 38(3):885-889. 
Khanzada, M. A., Lodhi, A.M. , Shahzad, S. (2004). Mango dieback and gummosis in Sindh, Pakistan caused by Lasiodiplodia theobromae. Plant Health Progress. Doi: 10.1094/ PHP- 0302- 01- DG.

Kim, N.S. and Lee, D.S . (2002) .Comparison of different extraction methods for analysis of fragrances from Lavandula species by gas chromatography-mass spectrometry. Journal of chromatography, 982: 31- 47.

Lawless,I.(1992).The encyclopedia of essential oils. Melbourne, Australia Element.

Lee, S.O., Choi, G.J., Jang, K.S. and Kim, J.C. (2007). Antifungal Activity of Five Plant Essential Oils as Fumigant Against Postharvest and Soilborne Plant Pathogenic Fungi. Plant Pathol. J., 23 (2): 97-102.

Lis-Balchin, M. and Hart, S. (1999).Studies on the mode of action the essential oil of lavender Lavandula angustifolia P.Miller) .Phytother Res., 13: 540.

Mahesh, B. and Satish, S. (2008).Antimicrobial activity of some important medicinal plant against plant and human pathogens. World J. Agri.Sci., 4(s):839-843.

Moraes, W.B.C. (1992). Alternative control of plant pathogens. Pesquisa Agropecuaria Brasileira, $27: 175-190$.

Muhammed, H.S. (2005). The use of Lawsonia inermis Linn (henna) in the management of burn wounded infection. African Journal of Biotech, (4): 934-937.

Ogundipe, O, Akinbiyi, O. and Moody, J.O.(1998).Antibacterial activites of essential ornamental plants. Nigeria.J.Natural Products\& Medicine,(2):46-47.

Paul, J.P., Brophy, J.J, Goldsack, R.J. and Fontaniella, B.(2004). Analysis of volatile components of Lavandula canariensis L. Mill., a Canary Islands endemic species, growing in Australia. Biochemical Systematics and Ecology,32 : 55-62.

Punithalingam, E. (1976). Botryodiplodia theobromae. CMI Descriptions of Pathogenic Fungi and Bacteria No. 519. (CAB International:Wallingford, UK).

Rossel, G., Espinoza C., Javier, M. and Tay, D. (2008). Regeneration guidelines: sweet potato and yam. In: Dulloo ME, Thormann I, Jorge MA, Hanson J. Crop specific regeneration guidelines [CD-ROM]. CGIAR System-wide Genetic Resource Programme, Italy. P. 9.

Sangeetha, G., Anandan, A. and Rani, S.U. (2011). Morphological and Molecular characterization of Lasiodiplodia theobromae from various banana cultivars causing crown rot disease in fruits. Archives of Phytopathology and Plant protection, pp. 1-12.

Scalbert, A. (1991). Antimicrobial properties of tannis .Phytochemistry, 30: 3875-3883.

Schwan, K.R.F. and Strangarlin, J.R.(2005).Extracts and essential oils of medicinal plants in the resistance induction against plant pathogens. Piracicaba, 125-138. 
Sharma, R. N. , Maharashi, R.P. and Gaur, R.B. (2010). Bioefficacy of indigenous plant extracts in controlling post -harvest stemend rot (Botryodiplodia theobromae) of kinnow fruits. Indian Journal of Horticulture, 67(3): 306-310.

Singh, A. and Singh, D.K. (2001) .Mollusicidal activity of Lawsonia inermis and itsbinaey and tertiary combinations with other plant terived mollusciides. Indian .J.Exp.Biol,(3):263-268.

Snedecor, G.W. and Conchran, W.G. (1968). Statistical Methods. The Lowa State Univ. Pres, Ames, Lowa, U.S.A.

Strangarlin, J. R., Schwan, K. R. F. ; Gruz, M. E. S. and Nozaki, M .H. (1999). Medicinal plants and alternative control of phytopathogens. Biotecnologia Ciencia \&Dessnvolvimento,(11):16-21.

Strangarlin, J.R. ,Schulz, D.G. , Franzener, G. , Assi, L. , Schwan ,K. R. F. and Kuhn, O. J. (2010). Induction of phytoalexins in soybean and sorghum by Saccharamyces boulardii. Arquivos do Instituto Biologico, 77: $91-98$.

Sutton, B.C. (1980). The Coelomycetes. Common Wealth Mycological Inst. Kew, Surrey.

Tariqu, H. S. , Khan, S.N. and Arshad, J.d. (2010).Management of corm rot disease of Gladiolus by plant extracts. (Part- Bioactive natural products.).Natural Product Research, 24:1131-1138.

Urs, N.V.R.R. and Dunteavy ,J. M. (1975) .Enthancement of bactericidal activity of a peroxidase system by phenolic compounds (Xanthomonas phaseolivar. sojensis, soybeans). Phytopathol, 65: 686- 690. 


\section{الملخص العربي}

مقاومة عفن جذور اللافندر باستخدام مستخلصات أوراق الحناء والكافور

$$
\begin{aligned}
& \text { "حنان محمد حرب على "ناهد سيد احمد الثايب " "على حسين الثاعر } \\
& \text { * معهد بحوث البساتين - مركز البحوث الزراعية - الجيزة - ج.م.ع. } \\
& \text { ** معهد بحوث امراض النبات - مركز البحوث الزراعية - الجيزة - ج.م.ع. }
\end{aligned}
$$

اجريت هذه التجربة فى مزرعة قسم بحوث النباتات الطبية والعطرية بالدقى خلال موسمى 2013/2012 بهدف


مرض عفن الجذور فى نبات اللافندر وكذلك النمو الخضري ونسبة الزيت ومكونات الزيت وكانت اهم النتائج

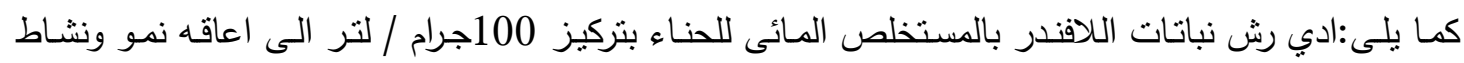

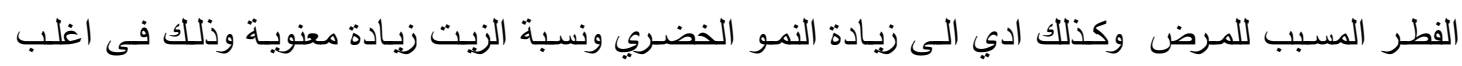
الحالات فى كلا الموسمين. وقد سجلت النباتات التى عوملت بالمستخلص المائى للكافور بنركيز 50جرام/ لنر اقل قيم وذلك فى كلا الموسمين • اما بالنسبة لتحليل مكونات الزيت فقد ادى الرش بالمستخلص المائى للحناء بتركيز • 100جرام / لترالى الحصول على اعلى نسبة للمكون الرئيسى فى الزيت (السنيول). 